\title{
Aglomerasi Perkotaan di Daerah Istimewa Yogyakarta
}

\author{
Mudrajad Kuncoro
}

Agglomeration has become a central attention in the literature of economic geography, business strategy and national competitiveness, and regional studies. However, we still know little of how commonand widespread the phenomenon of agglomeration across regions, cities, and industries.

This paper explores the nature of agglomeration, where it tends to locate in DIY, and the driving forces underpinning agglomeration. It found that urbanisation and industrialisation tend to merge and form an extended city of Yogyakarta. The pattern and dynamics of agglomeration has been extending, albeit bringing wider inequality spatially. Hence, a common "spaceless" regional development strategy is urgently reformed.

Key words: aglomerasi, industri, ketimpangan

Denduduk dunia makin lama semakin Perserikatan Bangsa-Bangsa (PBB) melaporkan bahwa hampir separo penduduk dunia tinggal di wilayah perkotaan (UN, 1998: 2). Laporan tersebut juga menyajikan proyeksi yang menarik: Pertama, begitu melewati milenium baru, untuk pertama kali dalam sejarah umat manusia, penduduk perkotaan akan melampaui jumlah pendudukyang tinggal di perdesaan. Kedua, pada tahun 2030 diperkirakan 3 dari 5 penduduk dunia akan tinggal di wilayah perkotaan, baik kota kecil, kota besar, maupun kota metropolitan. Beberapa pakar sependapat bahwa dasawarsa terakhir abad ke-20 akan menjadi saksi apakah penduduk perkotaan melebihi penduduk perdesaan untuk pertama kalinya dalam sejarah (Clark; 1996). Kendati fenomena ini amat monumental, kejadiann historis ini relatif kurang mendapat peihatian.
Tingkat urbanisasi di negara-negara Asia Tenggara lebih tinggi dibanding negaranegara Asia lainnya. Selama empat dasawarsa terakhir, tingkat urbanisasiyang diukur dengan persentase penduduk yang tinggal di daerah perkotaanmeningkat hampir dua kali lipat di negaranegara ASEAN (Tabel 1). Pada tahun 1960, tingkat urbanisasi di negara-negara ASEAN sebesar 20 persen, sedikit di bawah négaranegara Asia lainnya. Pada tahun 1985, hampir semua negara-negara ASEAN memiliki tingkat urbanisasi yang jauh lebih tinggi dibanding rata-rata negara Asia: Kendati demikian, pada skala global, tingkat urbanisasi di negara-negara ASEAN masih tergolong rendah. Ini terbukti dari tingkat urbanisasi dunia pada tahun 1960 dan 1995 masing-masing sebesar 34 persen dán 45 persen, yang lebih tinggi daripada ratä-rata tingkat urbanisasi ASEAN.

Industrialisasi telah menjadi kekuatan utama (driving force) di balik urbanisasi yang cepat di kawasan Asia.sejak dasawarsa. 
1980-an. Kecuali dalam kasus industri berbasis sumberdaya (resource-based industries), industri manufaktur cenderung berlokasi di dalam dan di sekitar kota. Pertanian dan industri berdampingan, bahkan kadang berebut lahan di seputar pusat-pusat kota. Pada gilirannya semakin mengaburkan perbedaan baku antara desa dan kota (McGee, 1991). Industri cenderung beraglomerasi di daerah-daerah di mana potensi dan kemampuan daerah tersebut memenuhi kebutuhan mereka, dan mereka mendapat manfaat akibat lokasi perusahaan yang saling berdekatan. Kota umumnya menawarkan berbagai kelebihan dalam bentuk produktifitas dan pendapatan yang lebih tinggi, yang menarik investasi baru, teknologi baru, pekerja terdidik dan terampil dalam jumlah yang jauh lebih tinggi dibanding perdesaan (Malecki, 1991). aktifitas ekonomi maupun penduduk di perkotaan, menjadi isu sentral dalam literatur geografi ekonomi (Krugman, 1998), strategi bisnis dan peningkatan daya saing nasional (Porter, 1998a; Porter, 1998b), dan studi-studi regional (Maskell, et al. 1997; Scott \& Storper, 1992). Ini disebabkan karena pertanyaan "mengapa" (why) industri manufaktur cenderung memilih berlokasi $\mathrm{di}$ dalam dan di sekitar kota-kota utama belum terjawab dengan mémuaskan. Kita masih belum memahami seberapa jauh dan menyebarnya fenomena aglomerasi antar daerah, kota, dan industri.

Artikel ini akan menfokuskan pada analisis dinamika aglomerasi di propinsi Daerah Istimewa Yogyakarta. Pertama, akan disajikan terlebih dulu apa yang dimaksud dengan aglomerasi. Kedua, di mana dan bagaimanakah perkembangan

Tabel 1. Urbanisasi di Negara ASEAN, 1995 dan 1960

\begin{tabular}{|l|cc|}
\hline Negara & \multicolumn{2}{|c|}{ Tingkat Urbanisasi (\%) } \\
& 1995 & 1960 \\
\hline Thailand & 20.0 & 12.5 \\
Indonesia & 35.4 & 14.6 \\
Philippines & 54.0 & 30.3 \\
Malaysia & 53.6 & 26.6 \\
\hline Brunei & 69.2 & 43.4 \\
\hline Cambodia & 20.4 & 10.3 \\
\hline Laos & 20.7 & 7.9 \\
\hline Vietnam & 19.4 & 14.7 \\
\hline ASEAN & 36.6 & $20: 0$ \\
\hline Asiä & 347 & 20.8 \\
\hline Worid & 45.3 & 33.6 \\
\hline
\end{tabular}

Tidak termasuk Singapura karena merupakan negara kota dengan $100 \%$ penduduk tinggal di kawasan perkotaan.

- Sumber: UN, 1998.

Oleh karena itu, dapat dimengerti apabila aglomerasi (agglomeration), baik aglomerasi di DIY, yang tidak dapat dipisahkan dengan adanya kaitan yang erat 
antara proses perkembangan kota dan industrialisasi. Ketiga, adanya aglomerasi aktivitas ekonomi dan penduduk di kota Jogja yang cenderung ke arah utara (baca: kabupaten Sleman) telah menyebabkan peningkatan ketimpaingan pembangunan antar kabujpaten/kota di DIY. Kabupaten Kulon Progo dan Gunung Kidul ternyata relatif tertinggal dibandingkan daerah lain di DIY. Masalahnya, mengapa-kedua daerah ini tertinggal? Bagaimanakah strategi percepatan pembangunan daerah tertinggal?

\section{Konsep Aglomerasi}

Apa yang dimaksud dengan aglomerasi? Montgomery mendefinisikan aglomerasi sebagai konsentrasi spasial dari aktifitas ekonomi di kawasan perkotaan karena "penghematan akibat lokasi yang berdekatan (economies of proximity)... yang diasosasiakan dengan kluster spasial darii. perusahaan, para pekerja, dan konsumen" (Montgomery, 1988).

Ini senada dengan Markusen (1996) yang menyatakan bahwa aglomerasi merupakan suatu lokasi yang "tidak mudah berubah" akibat adanya penghematan eksternal yang terbuka bagi semua perusahaan yang letaknya berdekatan dengan perusahaan lain dan penyedia jasajasa; dan bukan akibat kalkulasi perusahaan atau para pekerja secara individual. Markuser menulis bahwa agiomerasi menunjukkan:

"the stickiness of a place resides not in the individual locational calculus of firms or workers, but in the external economies available to each firm from its spatial conjunction with other firms and suppliers of services" (Markusen, 1996):
Dari kutipan-kutipan definisi di atas dapat ditarik benaing merah bahwa suatu aglomerasi tidak lebih dari sekumpulan kluster industri. Namun suatu kluster, atau superkluster di Brazil, atau'bahkan kumpulan kluster tidak dapat diidentikkan dengan suatu kota. Nama-nama populer seperti Silicon Valley di AS atau Sinos Valley di Brazil menunjukkan bentuk-bentuk geografis yang berbeda, demikian juga literatur kluster industri seperti EmiliaRomagna di Italia.

Perkembangan konsep dan pemikiran mengenai aglomerasi dapat dirangkum dalam Gambar 1. Gambar tersebut mempertihatkan bahwa setiap studi atau teori mengenai aglomerasi dapat digolongkan dalam perspektif klasik atau moderen (Kuncoro, 2002: bab2). Perspektif klasik percaya bahwa aglomerasi merupakan suatu bentuk spasial dan diasosiasikan dengan konsep "penghematan akibat aglomerasi" (economies of agglomeration) melalui konsep eksternalitas. Para pendukung perspektif ini telah meletakkan dasar-dasar model mikro mengenai eksternalitas akibat skala ekonomis (Fujita \& Ogawa, 1982; Fujita \& Thisse, 1996). Belakangan, jalur pemikiran ini ditindaklanjuti dengan berbagai studi empiris yang mencoba menganalisis dan mengestimasi besarnya skala ekonomis, sebagaimana terlihat dari karya Gelder (1994), Henderson (1988), dan Sveikauskas (1975). Sementara itu, para ahli ekonomi perkotaan mendefinisikan kota sebagai hasil dari produksi aglomerasi secara spasial. Pada gilirannya hal ini' mendorong tumbuhnya literatur mengenai formasi kota.

Perspektif moderen menunjukkan béberapa kelemahan teori Klasik mengenai aglomerasi. Pada konteks ini, tiga jalur pemikiran dapat diidentifikasi. Pertama, teori-teori baru mengenai.eksternalitas 
dinamis (dynamic externalities). Kedua, mazab pertumbuhan perkotaan. Ketiga, paradigma berbasis biaya transaksi. an, kebanyakan studi memformalkan model yang mencoba menjelaskan daya tarik lokasi kawasan perkotaan. Periode ketiga

\section{Gambar 1. Perkembangan Konsep dan Pemikiran Mengenai Aglomerasi}

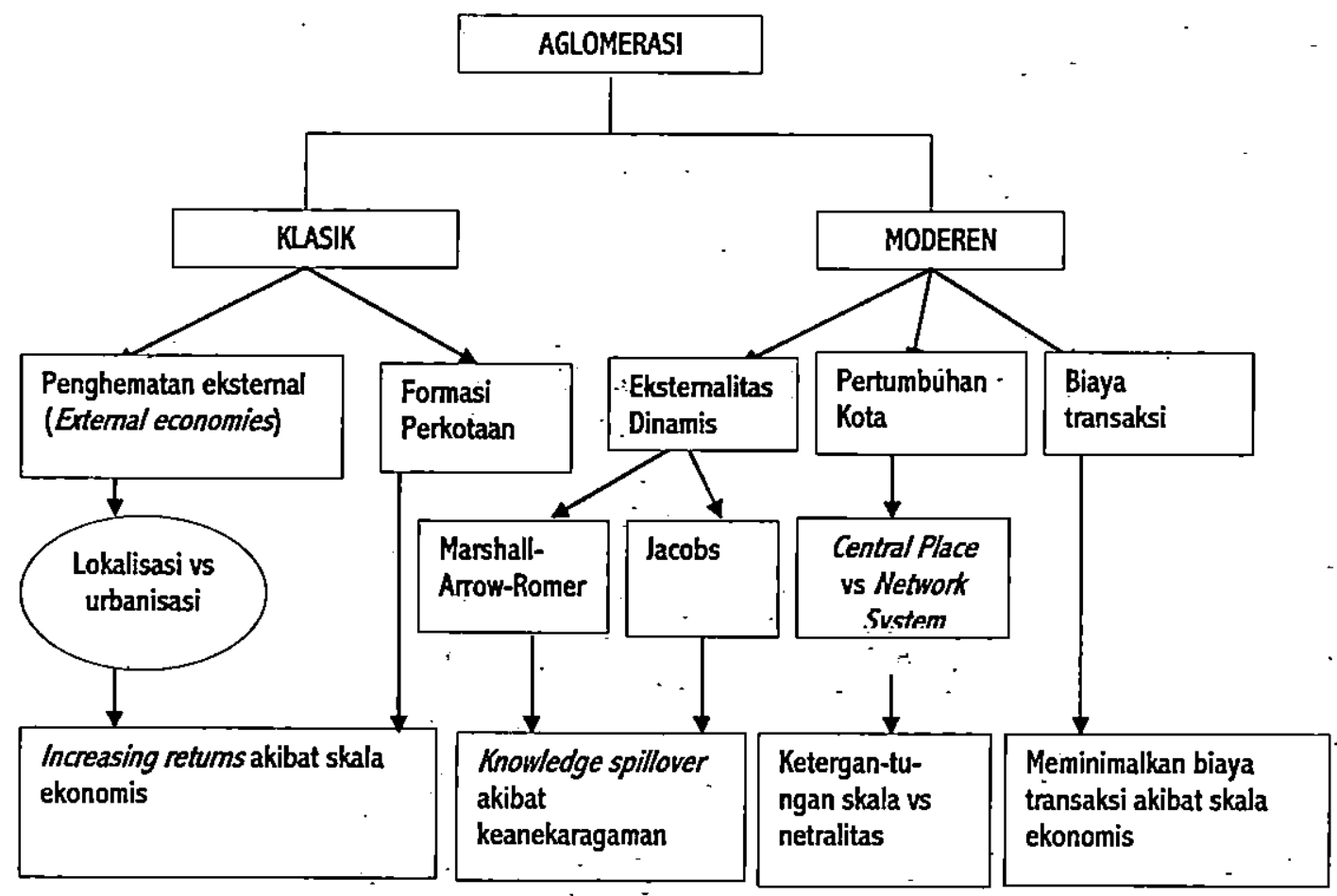

Sumber: Kuncoro (2000; 2002)

Dalam menjelaskan fenomena aglomerasi, banyak ekonom mendefinisikan kota sebagai hasil dari proses produksi aglomerași secara spasial. Dalam khasanah studi perkotaan yang secara. intensif dilakukan oleh para ekonom agaknya dapat ditdentifikasi empat periode evolusi pemikiran (Quigley, 1998: 127-9). Pada perode pertama, yaitu beberapa dasawairsa setelah Perang Dunial, fokus analisis adalah pada faktor-faktor yang mempengaruhi lokasi perusahaan dan rumah tangga dalam suatu kota. Pada periode kedua, yang dimulai pada pertengahan dasawarsa $1960-$ muncul dari analisis yang intensif mengenai kota-kota utama di AS (misalnya, New York) dan memperkenalkan konsep eksternalitas, yang muncul akibat skala ekonomis. Saat ini, kita berada dalam pertengahan periode keempat dalam mencoba memahami perrekonomian kota. Pada periode ini; kota digunakan untuk menganalisis hakekat dan sebab-sebab pertumbuhan ekonomi. Kebanyakan analisis aglomerasi secara implisit mengasumsikan bahwa formasi dan :perkembangan kota dapat dipahami bila mekanisme konsentrasi produksi secara spasial telah dimengerti dengan benar. 
Aglomerasi Perkotaan di DIY: Apa, Dimana, dan; Mudrajad Kuncoro

Tabel 2. Jumlah Penduduk per Kabupaten/Kota di Propinsi D.I. Yogyakarta, $1990-2000$

\begin{tabular}{|c|c|c|c|c|c|}
\hline \multirow{2}{*}{ Kabupaten/Kota } & \multicolumn{2}{|c|}{1990} & \multicolumn{2}{|c|}{2000} & \multirow{2}{*}{ Pertumbuhan } \\
\hline & Total & $\%$ & Total & $\%$ & \\
\hline 1. Kulonprogo & 372.321 & $.12,78$ & $\cdot-370.965$ & 11,88 & $-0,04$ \\
\hline 2. Bantul - & - -696.944 & 23,92 & 781.059 & 25,02 & $\cdot 1,19$ \\
\hline 3. Gunungkidul & 651.016 & 22,35 & $-\quad 670.544$ & - 21,48 & 0,31 \\
\hline 4. Sleman & 780.381 & 26,79 & 901.735 & 28,89 & 1,51 \\
\hline 5. Yogyäkarta & 412.392 & $-14,16$ & 397.398 & 12,73 & $-0,38$ \\
\hline Propinsi DIY & 2.913 .054 & 100,00 & 3.121.701 & 100 & 0,72 \\
\hline
\end{tabular}

Sumber: BPS D.I. Yogyakarta, 2000

Tabel 3. Jumlah Penduduk per Kecamatan di Kabupaten Sleman, 1999-2003

\begin{tabular}{|c|c|c|c|c|c|}
\hline \multirow{2}{*}{ Kecamatan/Kota } & \multicolumn{2}{|c|}{1999} & \multicolumn{2}{|c|}{2003} & \multirow[b]{2}{*}{ Pertumbuhan } \\
\hline & Total & $\%$ & Total & $\%$ & \\
\hline 1. Moyudan & 33.377 & 4,0 & 34.143 & 3,9 & 0,02 \\
\hline 2. Minggir & 34.308 & 4,1 & $34: 990$ & 4,0 & $-0,02$ \\
\hline 3. Seyegan & 41.880 & $5 ; 0$ & 42.861 & 4,8 & 0,02 \\
\hline 4. Godean & 56.531 & 6,7 & 59.320 & 6,7 & 0,05 \\
\hline 5. Gamping & 64.828 & 7,7 & 70.435 & 8,0 & 0,09 \\
\hline 6: Miati & 65.757 & $7 ; 8$ & 70.403 & 8,0 & 0,07 \\
\hline Z: Depok & 106.730 & 12,2 & $115.109^{\circ}$ & 13,0 & 0,08 \\
\hline 8. Berbah & 39.793 & 4,7 & 41.555 & 4,7 & 0,04 \\
\hline 9. Prambanan & 43.685 & 5,2 & 44.829 & 5,1 & 0,03 \\
\hline 10. Kalasan & 54.138 & 6,5 & 56.187 & 6,4 & 0,04 \\
\hline 11. Ngemplak & 43.712 & 5,2 & 46.661 & 5,3 & 0,07 \\
\hline 12. Ngaglik & 64.538 & $\underline{Z}, \bar{Z}$ & 70.050 & 7,9 & 0,09 \\
\hline 13. Sleman & 54.845 & 6,5 & 57.652 & 6,5 & 0,05 \\
\hline 14. Tempel & 46.032 & 5,5 & 47.751 & 5,4 & 0,04 \\
\hline 15. Turi & 32.141 & 3,8 & 33.742 & 3,8 & 0,05 \\
\hline 16. Pakem & 30.250 & 3,6 & 31.868 & 3,6 & 0,04 \\
\hline 17. Cangkringan & 26.083 & 3,1 & 27.171 & 3,1 & 0,05 \\
\hline Kabupaten Sleman & 836.628 & & 884.727 & . & r. \\
\hline
\end{tabular}

Șumber: Kabupaten Sleman Dalam Angka (1999 \&2003) 


\section{Aglomerasi di DIY}

DIY adalah provinsi yang unik secara demografik. Jumlah penduduk DIY hanya sekitar 3,1 juta jiwa pada tahun 2000 dan memiliki angka pertumbuhan penduduk $0,72 \%$, yang paling rendah di Indonesia. Dengan sekitar $60 \%$ penduduk tinggal di daerah perkotaan, DIY merupakan provinsi dengan penduduk paling padat kedua di lndonesia, setelah DKI Jakarta. Rata-rata tingkat kepadatan penduduk DIY pada tahun 2000 sebesar 980 orang $/ \mathrm{km}^{2}$, dengan tingkat kepadatan tertinggi di Kota Yogyakarta (12.228 orang $/ \mathrm{km}^{2}$ ) dan terendah di Gunung Kidul (451 orang $/ \mathrm{km}^{2}$ ).

Aglomerasi penduduk DIY cenderung berada di kota Jogjakarta dan kabupaten Sleman. Dengan laju pertumbuhan penduduk sebesar $1,51 \%$ per tahun selama 1990-2000, Kabupaten Sleman memiliki pertumbuhan penduduk tertinggi di Propinsi Daerah Istimewa Yogyakarta (lihat Tabel 2), diikuti Bantul dan Gunungkidul, sedang Kota Yogya dan Kulonprogo mengalami pertumbuhan negatif. Dari segi jumlah penduduk, Kabupaten Sleman juga memiliki penduduk terbesar diikuti Bantul, Gunungkidul, Jogja dan Kulonprogo.

Secara demografis hal ini menunjukkan bahwa di Sleman terdapat aktivitas yang tinggi dalam bidang kependudukan berupa bertambahnya para pendatang, meningkatnya angka kelahiran, dan banyaknya pasangan usia subur. Pada gilirannya, hal ini menunjukkan adanya fenomena perkotaan, terutama Extended Yogyakarta Urban Region, yaitu kota Yogyakarta ditambah kecamatan-kecamatan di Kabupaten Sleman yang berbatasan langsung dengan Yogyakarta.

Jika dilihat lebih rinci lagi, penyumbang jumlah penduduk yang tinggi di Kabupaten Sleman ternyata adalah Kecamatan Depok,
Gamping, Mlati, dan Ngaglik yang berada di bagian selatan Sleman. Kecamatankecamatan tersebut merupakan wilayah yang perkembangannya diarahkan untuk mendukung perkembangan (aglomerasi) Kota Yogyakarta. Keempat kecamatan ini mengalami pertumbuhan yang cepat dalam jumlah penduduk dan kegiatan ekonomi sebagai pengaruh banyaknya mahasiswa dan pendatang (lihat Tabel 3). Dengan demikian, bisa dikatakan bahwa wilayah tersebut merupakan pertumbuhan perkotaan/kawasan kota di Kabupaten Sleman.

Jika dilihat dilihat dari kepadatan penduduk per kecamatan per $\mathrm{km}$ persegi (lihat Tabel 4), kecamatan yang memiliki kepadatan penduduk di atas 1.800 orang per $\mathrm{km}^{2}$ selain Gamping,Ngaglik, Mlati dan Depok adalah Godean dan Kota Sleman. Walaupun jumlah penduduk di Godean dan Sleman di bawah 70 ribu (tahun 2003), kepadatan penduduknya cukup tinggi (di atas 1.800 orang per $\mathrm{km}^{2}$ ). Ngaglik yang jumlah penduduknya di atas 70 ribu orang, hanya mempunyai kepadatan penduduk sebesar 1.800 orang $/ \mathrm{km}^{2}$.

Dari uraian di atas, dengan melihat komposisi penduduk Sleman, maka dapat disimpulkan bahwa wilayah selatan Kabupaten Sleman yang meliputi kecamatan Gamping, Mlati, Ngaglik dan Depok ditambah lagi dengan Kecamatan Godean dan Sleman memang merupakan basis pertumbuhan perkotaan yang membentuk satu aglomerasi dengan Kota Jogja. Kecamatan Godean, Sleman dan Ngaglik, kendati terietak agak jauh dari Kota Yogyakarta, telah berkembang menjadi arah kegiatan masyarakat di wilayah kecamatan sekitarnya sehingga menjadi pusat pertumbuhan. Indikator kependudukan ketiga kecamatan/kota tersebut memiliki 
kepadatan penduduk yang cukup tinggi yang mencerminkan tingginya aktivitas kependudukan sebagai-salah satu fenomena perkotaan. dilakukan dengan melihat konsentrasi spasial per kecamatan dari industri Besar dan Menengah (IBM) yang ada di Kabupaten

Tabel 4. Kepadatan Penduduk per-Kecamatan di Kabupaten Sleman, 2003

\begin{tabular}{|c|c|c|}
\hline Kecamatan & Penduduk & $\begin{array}{c}\text { Kepadatan Penduduk per } \\
\mathrm{Km}^{2}\end{array}$ \\
\hline Moyudan & 34,143 & 1.236 \\
\hline Minggir & 34.990 & 1.283 \\
\hline Sayegan & $\begin{array}{r}-42.861 \\
\end{array}$ & 1.610 \\
\hline Godean & 59.320 & 2.210 \\
\hline Gamping & 70.435 & 2.408 \\
\hline Mlati & 70.403 & 2.469 \\
\hline Depoḱ & $115: 109$ & 3.238 \\
\hline Berbah & 41.555 & 1.808 \\
\hline Prambanan & 44.829 & 1.084 \\
\hline Kalasan & 56.187 & 1.568 \\
\hline Ngemplak & 46.661 & 1.307 \\
\hline Ngaglik & 20.050 & 1.819 \\
\hline Slemañ & 57.652 & 1.841 \\
\hline Tempel & 47.751 & 1.470 \\
\hline Turi & 33.742 & 783 \\
\hline Pakem & 31.868 & 727 \\
\hline Cangkringan & 27.171 & 566 \\
\hline Jumlah & 884.727 & 1.539 \\
\hline
\end{tabular}

Sumber: BPS Kabupaten Sleman, $2003^{-}$

Dinamika aktivitas ekonomi di DIY menimbulkan konsentrasi aktivitas ekonomi di kota Yogya dan kabupaten Sleman. Aglomerasi ekonomi di kedua daerah ini nampaknya tumbuh pesat, sebagaimana tercermin dari tingginya pertumbuhan ekonomi yang melebihi rata-rata DIY (lihat gambar 2). Menjamurnya rumah makan; rumah kos, berbagai aktivitas perdagangan dan jasa, berjalan seiring dengan dibangunnya universitas dan hotel.

Apakah aglomerasi penduduk juga sejalan dengan aglomerasi industri di DIY? Identifikasi wilayah perkotaan juga bisa
Sleman. Dengan menggunakan metode identifikasi kluster yang telah dikembangkan dalam literatur Industri (Kuncoro, 2002), Gambar 3 menyajikan peta lokasi IBM Kabupaten Sleman. Terlihat bahwa konsentrasi IBM berada di kawasan selatan Kabupaten Sleman, yang juga merupakan wilayah aglomerasi Kota Yogyakarta. Adanya akses jalan, khususnya ring road dan jalan raya yang menghubungkan Kota Yogyakarta dan Magelang, ikut berperanan dalam membentuk aglomerasi índustri di sepanjang kedua jalan ini. 
Topik: Keterpaduan Sektor Formal dan Informal Perkotaan

Gambar 2. Pertumbuhan PDRB Kabupaten/Kota di DIY, 1992-2003

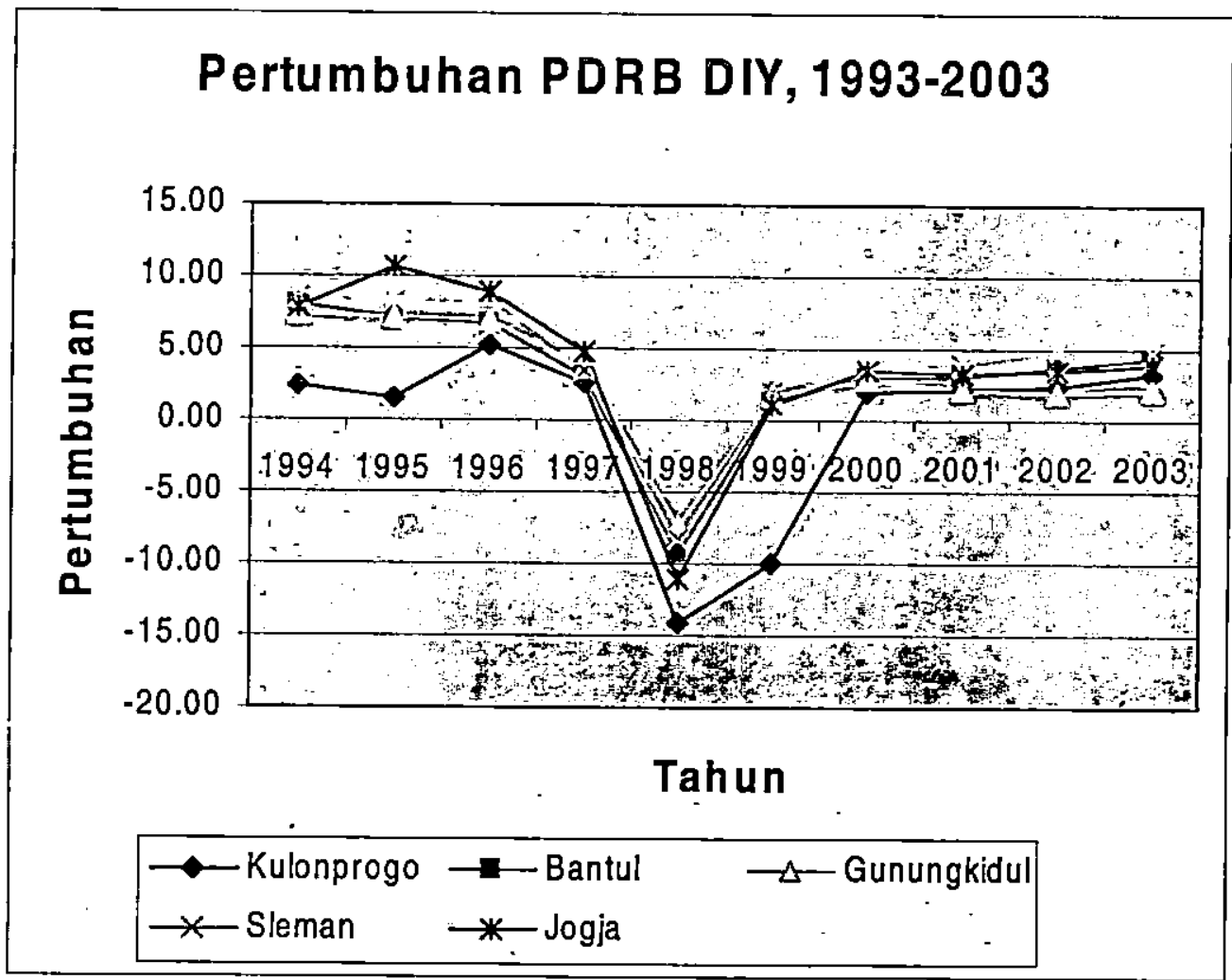

(Menurut Harga Konstan 1993, dalam \%)

\section{Ketimpangan Antar Daerah di DIY}

Pertumbuhan ekonomi dan aglomerasi aktivitas ekonomi di Kota Yogyakarta dan Kabupaten Sleman ternyata telah jauh meninggalkan daerah lainnya. Dengan menggunakan sejumlah indikator ekonomi dan sosial, harus diakui Gunung Kidul dan Kulon Progo relatif memang tertinggal. Selama 1997-2000, rata-rata kabupaten/ kota di. DIY mengalami kontraksi pertumbuhan ekonomi-3,11\%, dengan ratarata PDRB per kapita $R p 1,66$ juta (lihat Tabel 5). Pada periode krisis tersebut, Gunung Kidul mengalami pertumbuhan $-1,2 \%$, bahkan Kulon Progo lebih parah anjlok 8,5\%; PDRB per kapita Gunung Kidul dan Kulon Progo masing-masing Rp 1,36 juta dan Rp 973,2 ribu. Selama 2001-2003, pertumbuhan ekonomi kabupaten/kota di DIY sudah mulai pulih dengan rata-rata $3,16 \%$, dengan rata-rata PDRB per kapita Rp 1,79 juta. Pada periode awal otonomi daerah ini, Gunung Kidul mengalami pertumbuhan positif 2,1\% dan Kulon Progo. tumbuh 2,6\%; PDRB per kapita Gunung Kidul dan Kulon Progo masing-masing Rp 1,44 juta dan Rp 999,7 ribu.

Sebelum tahun 1997, Gunung Kidul dikenal sebagai kabupaten yang paling 
Aglomerasi Perkotaan di DIY: Apa, Dimana, dan; Mudrajad Kuncoro

Gambar 3. Peta Sebaran Industri Menengah dan Besar per Kecamatan di Kabupaten Sleman Berdasarkan Penyerapan Tenaga Kerja, 2001

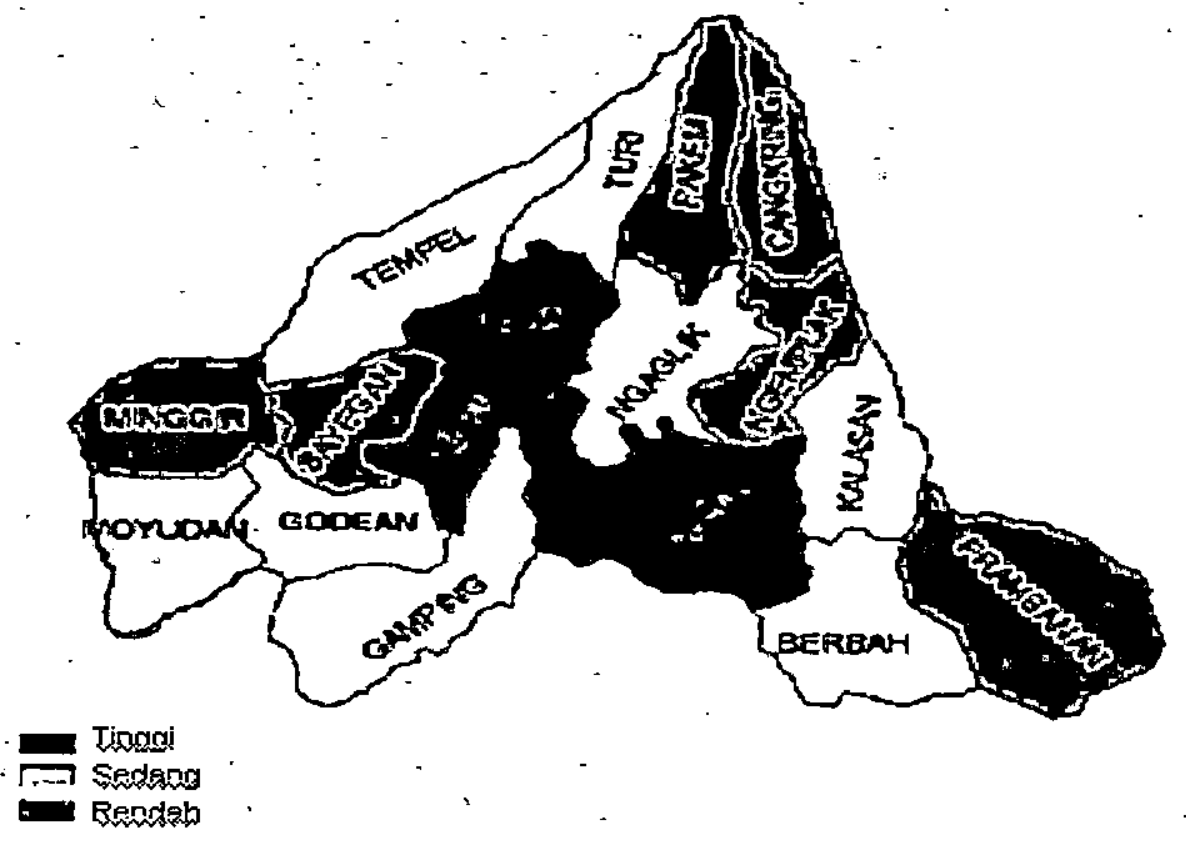

Sumber: Kuncoro, et al. (2005)

Tabel 5. Rata-rata Pertumbuhan Ekonomi dan PDRB per Kapita

\begin{tabular}{|c|c|c|c|c|}
\hline \multirow{2}{*}{$\begin{array}{l}\text { Kabupaten/ } \\
\text { Kota }\end{array}$} & \multicolumn{2}{|c|}{$1997-2000$} & \multicolumn{2}{|c|}{$2001-2003$} \\
\hline & $\begin{array}{l}\text { Pertumbuhan } \\
\text { ekonomi* }\end{array}$ & $\begin{array}{l}\text { PDRB per } \\
\text { kapita }^{\star \star}\end{array}$ & $\begin{array}{l}\text { Pertumbuhan } \\
\text { ekonomi }^{\star}\end{array}$ & $\begin{array}{l}\text { PDRB per } \\
\text { kapita**}\end{array}$ \\
\hline Jogjakarta & $-2,67$ & 3.310 .478 & 3,37 & 3.679 .107 \\
\hline Sleman & $-1,17$ & 1.588 .300 & 4,16 & 1.700 .146 \\
\hline KulonProgo & $-8,53$ & 973.190 & 2,60 & 999.686 \\
\hline Bantul & $-2,01$ & 1.068 .987 & 3,59 & 1.132 .711 \\
\hline GunungKidul & $-1,17$ & 1.359 .180 & 2,09 & 1.439 .210 \\
\hline Rata-rata DIY & $-3,11$ & 1.660 .027 & 3,16 & 1.790 .172 \\
\hline
\end{tabular}


tertinggal di DIY. Namun, ternyata selama 1997-2003, Gunung Kidul sudah jauh berubah. Rekor pertumbuhan ekonomi Gunung Kidul ternyata melebihi rata-rata kabupaten/kota di DIY. Artinya, tingkat pembangunan di Kabupaten tersebut amat pesat di atas rata-rata daerah lain di DIY. Kendati demikian, PDRB per kapitanya masih di bawah rata-rata DIY. Ini mencerminkan masih rendahnya kesejahteraan masyarakat. Tingkat kemiskinan di kabupaten Gunungkidui memang masih substansial.

Tabel 5 juga memperlihatkan perubahan mendasar yang layak dicatat di DIY adalah pertumbuhan ekonomi. Uji beda rata-rata pertumbuhan ekonomi daerah kabupaten/kota di DIY terbukti signifikan, sementara PDRB per kapita tidak signifikan. Dengan kata lain, dilihat dari perspektif ekonomi, rekor perubahan rata-rata pertumbuhan ekonomi sebelum dan setelah otonomi daerah amat meyakinkan: dari $3,1 \%$ menjadi $3,16 \%$.
Indikator sosial, terutama kemiskinan dan Indeks Pembangunan Manusia (IPM), juga menunjukkan kesimpulan serupa (lihat tabel 6). IPM di kabupaten Gunung Kidul dan Kulon Progo juga berada dalam papan bawah pada tahun 1999, yaitu masingmasing 63,6 dan 65,8 , yang jauh di bawah rata-rata IPM DIY sebesar 68,7. Padahal IPM DIY tercatat memegang peringkat nomor 2 terbaik secara nasional. Pada tahun 2002, IPM DIY turun menjadi peringkat ke-3; sementara peringkat IPM Kabupaten Gunung Kidul meningkat menjadi urutan ke140 namun Kulon Progo justru mengalami penurunan peringkat menjadi urutan ke 76 .

Rekor IPM di DY sejalan dengan catatan angka kemiskinan. Rata-rata tingkat kemiskinan untuk Propinsi DIY tahun 2003 adalah $19,1 \%$, dengan urutan kabupaten yang memiliki tingkat kemiskinan tertinggi adalah Gunung Kidul (25,2\%), diikuti Kulon Progo $(25,1 \%)$, kabupaten Bantul $(18,6 \%)$, kabupaten Sleman $(15,5 \%)$, dan kota Yogyakarta $(12,8 \%)$.

Tabel 6. Peringkat Pembangunan Manusia

\begin{tabular}{|l|c|c|c|c|}
\hline \multirow{2}{*}{ Kabupaten/kota } & \multicolumn{2}{|c|}{ IPM } & \multicolumn{2}{c|}{ Peringkat IPM } \\
\cline { 2 - 5 } & 1996 & 2002 & 1996 & 2002 \\
\hline Kulon Progo & 70 & 69,4 & 68 & 76 \\
\hline Bantul & 69,5 & 68,4 & 79 & 94 \\
\hline Gunung Kidul & 65,3 & 67,1 & 187 & 140 \\
\hline Sleman & 72,9 & 69,8 & 33 & 30 \\
\hline Yogyakarta & 76,1 & 72,7 & 5 & 3 \\
\hline DIY & 71,8 & 70,8 & 2 & 3 \\
\hline
\end{tabular}

Sumber: BPS, Bappenas; UNDP (2004) 


\section{Faktor Penyebab Ketimpangan}

Salah satu penyebab utama ketertinggalan Gunung Kidul dan Kulon Progo diakibatkan oleh kebijakan pembangunan yang terlalu bertumpu pada dimensi sektoral. Ini jelas tampak dengan dominannya penerapan asas dekonsentrasi dan orientasi sektoral pemerintah pusat. $\mathrm{Di}$ daerah nampaknya tidak jauh berbeda. Ini terlihat dari kuatnya fanatisme dinas dan pendekatan sektoral dalam Propeda/ Renstrada. Ini tercermin dari dokumendokumen perencanaan yang tidak ada rincian program maupun aksi hingga tingkat kecamatan, apalagi kelurahan. RUTRW (Rencana Umum Tata Ruang Wilayah) nampaknya dalam praktek tidak banyak dimasukkan dalam Renstrada, tak lebih hanya sebagai "tempelan". Bahkan di banyak daerah RUTRW sering dikalahkan dengan .obsesi kepala daerah yang berorientasi jangka pendek dan pragmatis, sejalan dengan masa jabatannya.

Belum dimasukkannya dimensi spàsial dalam perencanaan pembangunan disadari ketika ketimpangan antardaerah mulaj terasa. Di banyak kasus, pertumbuhan ekonomi tidak selalu sejalan dengan pemerataan. Ekonom menyebutnya sebagai trade-off. Indeks entropi Theil, sebagai indikator ketimpangan spasial, menunjukkan trend peningkatan yang signifikan selama 1991-2002 (lihat Gambar 4). Artinya, memang ada indikasi kuat terjadinya ketimpangan aktivitas ekonomi antar daerah di DIY meskipun khusus untuk Kabupaten Sleman mengalami tren penurunan.

\section{Gambar 4. Ketimpangan Antardaerah di DIY}

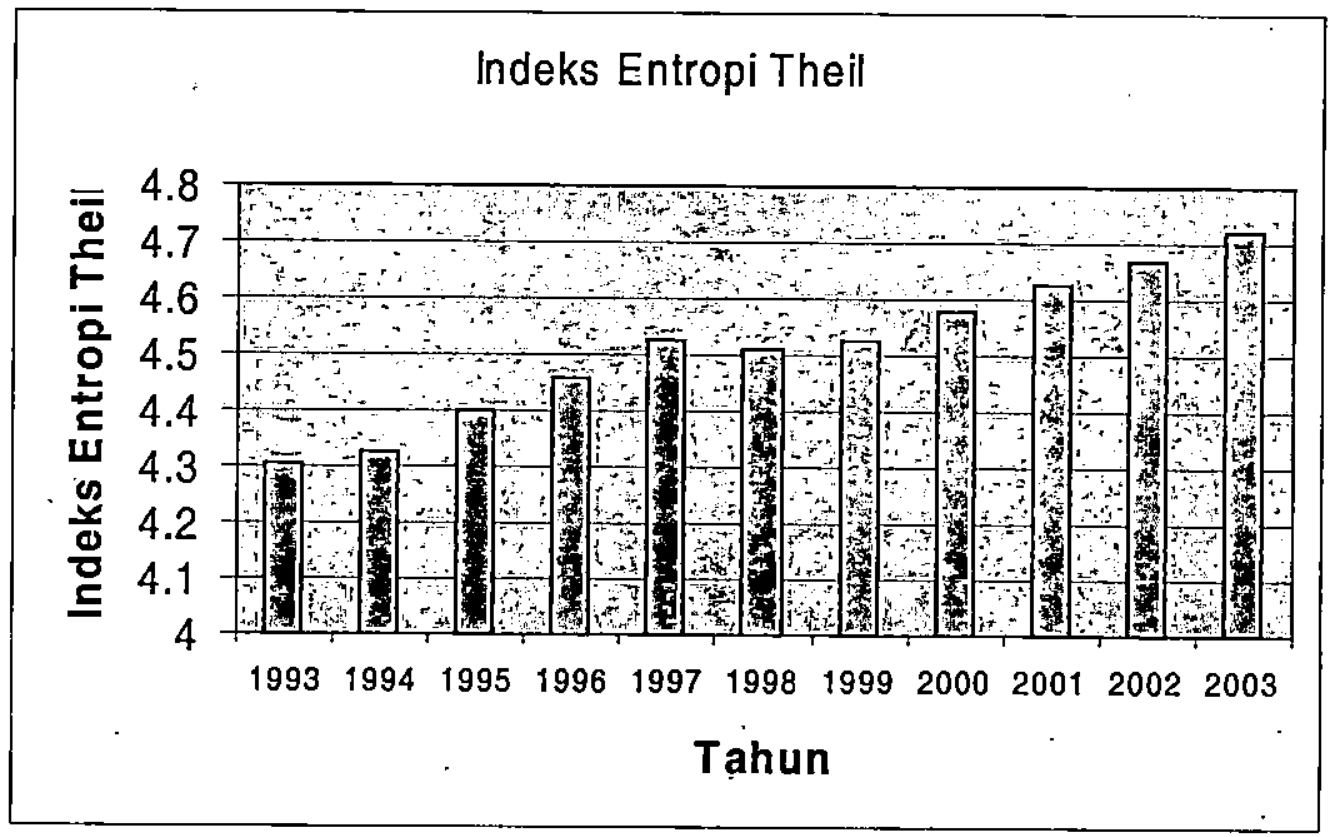

Sumber: Diolah dari BPS 
Diabaikannya dimensi spasial membuat warna pembangunan daerah ditentukan "mekanisme pasar". Akibatnya modal dan orang cenderung memilih daerah yang menawarkan retum yang lebih tinggi dan menarik, yang pada gilirannya daerah yang maju semakin maju, yang tertinggal tetap tertinggal. Pertanyaannya, mengapa tipologi daerah di DIY seperti itu? Faktor apa di balik perubahan positioning daerah kabupaten/kota ini?

Di kalangan para ahli ekonomi regional dikenal setidaknya dua teori. Pertama, teori kutub pertumbuhan (growth pole theory), yang menjelaskan adanya konsentrasi pertumbuhan daerah di pusat (core), yang tidak selalu berdampak positif bagi daerah pinggiran (hinterland). Boleh dikata, kutub pertumbuhan di provinsi DIY adalah kota Jogja, yang selama 15 tahun terakhir cenderung berkembang ke utara khususnya ke wilayah kabupaten Sleman.

Kedua, teori aglomerasi ekonomi, yang menjelaskan peranan urbanization economies dan localization economies. 'Penghematan urbanisasi' terjadi karena orang dan investor lebih suka memilih kawasan perkotaan, yang menawarkan penghematan biaya akibat kemudahan aksesibilitas dan keberadaan infrastruktur kota. 'Penghematan lokalisasi' muncul karena kedekatan geografis terhadap sumber bahan baku, tenaga kerja, dan knowledge spillover, menawarkan manfaat konsentrasi spasial.

\section{Kesimpulan}

Artikel ini telah mencoba memberikan bukti empiris adanya perkembangan aglomerasi di DIY, yang temyata membentuk aglomerasi penduduk dan industri pada saat yang bersamaan. Aglomerasi berada di wilayah kota Yogyakarta, yang juga mencakup kecamatan-kecamatan di wilayah kabupaten Sleman yang langsung berbatasan dengan kota ini. Adanya aglomerasi aktivitas ekonomi dan penduduk di kota Jogja yang cenderung ke arah utara (baca: kabupaten Sleman) telah menyebabkan peningkatan ketimpangan pembangunan antar kabupater/kota di DIY.

Dalam konteks ini, diperlukan reorientasi strategi pembangunan daerah. Pertama, strategi pembangunan ekonomi lokal perlu menekankan dimensi spasial. Pendekatan kluster bagi pengembangan bisnis di daerah merupakan trend, yang banyak dianut di banyak negara (Kuncoro, 2002; Porter, 1998). Implikasinya, bagi daerah perlu mengkombinasikan pendekatan sektoral berbasis kluster: di mana bisnis/sektor unggulan daerah cenderung berlokasi dan mengelompok?

Kedua, ketertinggalan Gunung Kidul dan Kulon Progo barangkali karena mayoritas kelurahan/desanya masih termasuk kawasan perdesaan. Dari 18 kecamatan di Gunung Kidul, 139 dari 144 kelurahan/desa tergolong kawasan perdesaan. Dari 12 kecamatan di Gunung Kidul, 75 dari 88 kelurahan/desa tergolong kawasan perdesaan. Desa, yang jauh dengan keramaian dan hiburan, umumnya masih tertinggal dalam berbagai jenis infrastruktur. Karena itu, dapat dipahami, kantong kemiskinan umumnya berada di daerah perdesaan. Oleh karena itu, strategi pembangunan perdesaan nampaknya perlu. diintegrasikan dengan strategi pengembangan kota, dengan mengembangkan keterkaitan desa-kota (rural-urban linkage) dan jejaring antarkota (network cities).

Ketiga, diperlukan big push bagi percepatan pembangunan daerah tertinggal. 'Daya dorong' yang tinggi bisa diartikan modal dan infrastruktur. Aksesibilitas modal dan 
keberpihakannya kepada daerah yang tertinggal merupakan langkah strategik. Pengembangan infrastruktur ekonomi, yang menghubungkan daerah tertinggal dengan pusat-pusat bisnis, pasar, dan jejaring internasional, nampaknya perlu menjadi priontas bagi pemerintah pusatmaupun daerah.

Di sinilah letak pentingnya menyusun perencanaan jangka panjang dan rencana aksi bagi daerah tertinggal. Sayangnya saat ini belum ada koherensi dan sinergi antara visi maupun Renstrada antardaerah di DIY. Tabel 7 merangkum visi dan misi seluruh kabupaten/kota dan provinsi di DIY: Terlihat masing-masing daerah memiliki visi dan misi yang berbeda, sejalan dengan tuntutan masyarakat, kebutuhan daerah, dan perspektif perencanaan di masing-masing daerah. Apalagi saat ini fanatisme sektoral mulai beralih menjadi fanatisme daerah yang cenderung berlebihan. Rencana Aksi Strategis Pengembangan Perekonomian
DIY dan Outline Business Plan ( $K R, 10 / 12 /$ 2004), yang disusun PSPPR UGM dan Bappeda DIY, nampaknya belum secara eksplisit memasukkan ketiga usulan reorientasi strategi pembangunan daerah $\mathrm{di}$ atas. Perhatian terhadap daerah tertinggal masih minimal.

Implikasinya, bagi pemda, DPD dan DPRD, jelas merupakan pekerjaan rumah yang tidak ringan, terutama bagaimana mempercepat pembangunan daerah tertinggal. DIY membutuhkan kutub-kutub pertumbuhan ekonomi baru di luar Kota Jogja dan Sleman agar pemerataan aktivitas ekonomi, dan pada gilirannya pemerataan pendapatan dapat meningkat di mendatang. Pembangunan mal baru, yang semua berada di kota Jogja dan Sleman, perlu diarahkan agar menciptakan keterkaitan dengan aktivitas ekonomi rakyat, yang mayoritas tinggal di perdesaan dan daerah tertinggal.

\section{Tabel 7. Visi dan Misi Propinsi, Kabupaten dan Kota di DIY}

\begin{tabular}{|c|c|c|c|}
\hline No. & $\begin{array}{c}\text { XAB/KOTAPR } \\
\text { OP }\end{array}$ & Vist & HAS \\
\hline 1 & $\mathrm{DIY}$ & $\begin{array}{l}\text { Ternujudnya permbangunan regional sebagai wahana } \\
\text { mentju pada kondisi DIY pada tahun } 2020 \text { sebagai pusat } \\
\text { pendidikan, budaya dan daerah tujuan wisata terkemuka } \\
\text { dalam lingkurngan masyarakat yang majı, mandiri, } \\
\text { sejahtera lahir batin, didukung oleh nilaj-rilai kejuangan } \\
\text { dan pemerintahan yang bersih dalam pemerintahan yang } \\
\text { baik dengan mengembangkan ketahanan sosial, budaya } \\
\text { dan sumber daya berkelanjutan }\end{array}$ & 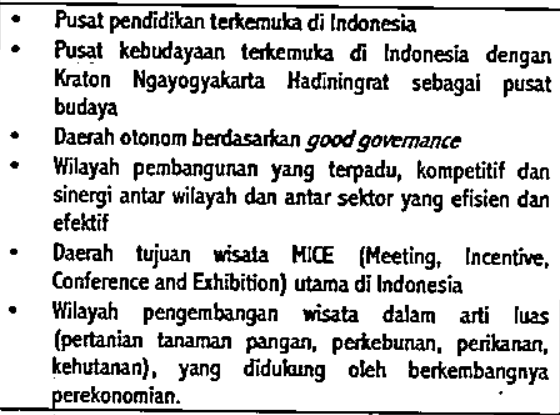 \\
\hline 2 & $\begin{array}{l}\text { Kota } \\
\text { Yogyakarta }\end{array}$ & $\begin{array}{l}\text { Terwujudnya pernbangunan Kota Yogyakarta dalam } \\
\text { rangka meletakkan kerangka dasar menuju Kota } \\
\text { Yogyakarta sebagai kota pendidikan yang berkualitas, } \\
\text { kota pariwisata yang berbudaya, pertumbuhan dan } \\
\text { pelayanan jasa prima, ramah lingkungan serta masyarakat } \\
\text { madani yang didukung pemerintah yang baik. }\end{array}$ & $\begin{array}{l}\text { Kota Yogyakarta menuju kota pendidikan yang } \\
\text { berkualitas didukung oleh masyarakat, swasta yang } \\
\text { berilmu pengetahuan dan teknologi } \\
\text { - Kota Yogyakarta menuju sebagai kota pariwisata } \\
\text { - Kota Yogyakarta sebagai pusat pertumbuhan dan } \\
\text { pelayanan jasa } \\
\text { - Menjaga, melestarikan dan mengembangkan lingkungan } \\
\text { - Malam rangka pembangunan yang berkelanjutan } \\
\text { - Memajukan warga masyarakat datam setiap aspek } \\
\text { kehidupan }\end{array}$ \\
\hline
\end{tabular}




\section{Topik: Keterpaduan Sektor Formal dan Informal Perkotaan}

\begin{tabular}{|c|c|c|c|}
\hline 3 & $\begin{array}{l}\text { Kabupaten } \\
\text { Bantul }\end{array}$ & $\begin{array}{l}\text { Bantul Projotamansari sejahtera, demokratis, dan agamis. } \\
\text { (Projotamansari: produktif dan profesional, hijau dan } \\
\text { rindang,tertib, aman, sehat, asri. }\end{array}$ & $\begin{array}{l}\text { - Mewujudkan kesejahteraan dengan prioritas } \\
\text { mencerdaskan dan meningkatkan derajat kesehatan } \\
\text { masyarakat } \\
\text { - Mewujudkan penyelenggaraan pemerintahan yang baik } \\
\text { dan bertanggungjawab } \\
\text { - Mewujudkan demokratisasi dalam segala aspek } \\
\text { kehidupan, menghormati hak asasi manusia, dan } \\
\text { menjamin tegaknya supremasi hukum } \\
\text { - Mewujudkan peningkatan produksi, produktifitas, dan } \\
\text { nilaj tambah hasit-hasil potensi daerah yang } \\
\text { berkelanjutan dan berwawasan lingkungan. }\end{array}$ \\
\hline 4 & $\begin{array}{l}\text { Kabupaten } \\
\text { Sleman }\end{array}$ & $\begin{array}{l}\text { Terwujudnya masyarakat Kabupaten Sleman yang maju, } \\
\text { sejahtera, lestari, mandin, berdaya saing, damai, } \\
\text { demoksatis, agamis dan berkeadilan }\end{array}$ & $\begin{array}{l}\text { - Penerapan dan pengembangan tekrologi } \\
\text { - Peningkatan pertumbuhan ekonomi } \\
\text { - Peningkatan derajat kesehatan masyarakat } \\
\text { - Pelestarian lingkungan hidup } \\
\text { - Pelestarian nilai-nilai budaya } \\
\text { - Penataan dan optimalisasi birokrasi } \\
\text { - Pemberdayaan masyarakat dalam pembangunan } \\
\text { - Peningkatan perididikan masyarakat } \\
\text { - Peningkatan penegakan supremasi hukum } \\
\text { - Peningkatan kesadaran berdemokrasi } \\
\text { - Peningkatan kualitas beragama } \\
\text { - Pemerataan peranfaatan sumber daya }\end{array}$ \\
\hline 5 & $\begin{array}{l}\text { Kabụpaten } \\
\text { Kulon Progo }\end{array}$ & $\begin{array}{l}\text { Terwujudnya peningkatan kesejahteraan masyarakat } \\
\text { Kulon Progo, didukung pemerintahan yang baik dan } \\
\text { bersih, pengembangan sumber daya daerah, ketahanan } \\
\text { sosial budaya dan berwawasan kebangsaan. }\end{array}$ & $\begin{array}{l}\text { - Penyelenggaraan pemerintahan yang baik dan bersih } \\
\text { ditandai dengan kredibilitas aparatur pemerintahan } \\
\text { yang profesional, transparan dan akuntabel serta } \\
\text { terwujudnya deriokrasi dan penegakan supremasi } \\
\text { hukum - } \\
\text { - Pengembangan sumber daya daerah baik SOM melalui } \\
\text { pengembangan pendidikan maupun SDA terutama } \\
\text { komoditas pertanian dalam arti luas dengan } \\
\text { mengembargkan ekonomi kerakyatan dengan prioritas } \\
\text { pada agrobisnis } \\
\text { Ketahanan sosial budaya yang diwujudkan dengan } \\
\text { pelaksanaan pembangunan kesehatan, peningkatan } \\
\text { kesejahteraan sosial, kualitas beragama, } \\
\text { pengembangan seni budaya dan pariwisata, } \\
\text { peningkatan peran perempuan, pemuda, dan olah raga } \\
\text { Penanaman wawasan kebangsaan untuk mempertebal } \\
\text { rasa persatuan dan kesatuan antar selurih warga } \\
\text { masyarakat }\end{array}$ \\
\hline 6 & $\begin{array}{l}\text { Kabupaten } \\
\text { Gunung Kidul }\end{array}$ & $\begin{array}{l}\text { Terwujudnya Kabupaten Gunung Kidul sebagai daerah } \\
\text { pengembangan pertanian, industri kecil dan menengah, } \\
\text { sehat, pariwisata yang berbudaya dengan didukung } \\
\text { pemerintahan yang baik dan seuber daya manusia yang } \\
\text { berkualitas menuju kemandirian serta peningkatan taraf } \\
\text { hidup masyarakat tahun } 2005 .\end{array}$ & 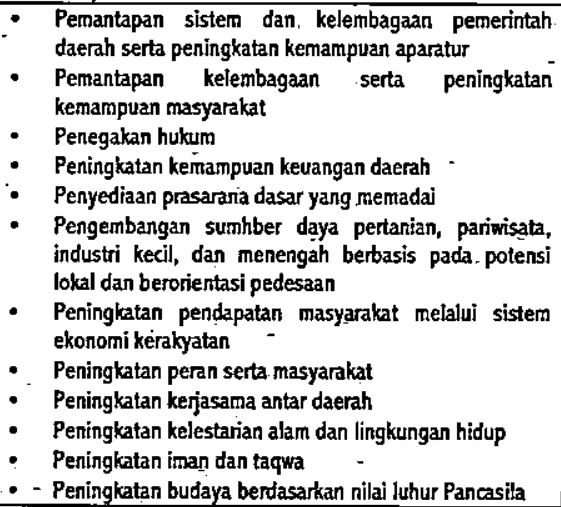 \\
\hline
\end{tabular}

\section{Sumber: Pemda DIY (2003); Kuncoro (2004: bab 4)}


Aglomerasi Perkotaan di DIY: Apa, Dimana, dan; Mudrajad Kuncoro

\section{Daftar Pustaka}

Badan Pusat Statistik. Survei Industri Manufaktur Menengah dan Besar, Beberapa Edisi.

Badan Pusat Statiștik, Bappenas, UNDP, 2004. The Economics of Democracy: Financing Human Development in Indonesia. Jakarta: BPS.

Black, Duncan and Henderson, Vernon. (1999), A Theory of Urban Growth, Joumal of Political Economy, 107(2): 253-284.

Carlino, Gerald A. 1998, Trend in Metropoli$\tan$ Employment Growth, Federal Reserve Bank of Philadelphia, JuliAgustus, 13-21.

Clark, D., 1996. Urban World: Global City. London: Routledge.

Ellison, Glenn and Glaeser, Edward L., 1999, The Geographic Concentration of Industry: Does Natural Advantage Explain Agglomeration?, The American Economic Review, 89(2): 311-316

Firman, Tommy, 1992, The Spatial Pattern of Urban Population Growth in Java, 1980-1990, Bulletin of Indonesian Economic Studies, 28(2): 95-107.

Fujita, M., \& Ogawa, H., 1982. Multiple Equi-libria and Structural Transition of Nonmonocentric Urban Cońfíguration. Regional Science and Urban Economics, 12, 161-196.

Fujita, M., \& Thisse, J.-F. (1996). The Economics of Agglomeration. Journal of Japanese and Intemational Economics, 10, 339-78.
Gelder, L. v. (1994). Industrial Agglomeration and Factor Market Segmentation with Empirical Applications to Indonesia. Unpublished Ph.D Dissertation, Cornell University, US.

Glaeser, E. L., Kallal, H. D., Scheinkman, J. A., and Shleifer, A., 1992, Growth in Cities, Journal of Political Economy, 100(6): 1126-1152.

Hayter, Roger. 2000, The Dinamicc of Industrial Location: The Factory, the Firm, and the Production System, Chichester: John Wiley \& Sons.

. Henderson, J. V.,1988. Uman Development, Theory, Fact, and Illusion. New York: Oxford University Press.

Henderson, J. Vernon, Kuncoro, A., and Nasution, D., 1996, The Dynamics of Jabotabek Development, Bulletin of Indonesian Economic Studies, 32(1): 71-95.

Jones, G. W. and Mamas, S. G. M. 1996, The Changing Employment Structure of the Extended Jakarta Metropolitan Region, Bulletin of Indonesian Economic Studies, 32(1): 51-70.

Kelly, Philip F.1999, Everyday Urbanization: The Social Dynamics of Development ini Manila's. Extended Metropolitan Region, International Journal of Urban Regional Research, 23(2): 283303.

Krugman, P. 1996, Urban Concentration : The Role of Incresing Returns and Transport Costs, International Regional Science Review, 19(1\&2): 530. 
Krugman, P. 1998. Space: The Final Frontier. Joumal of Economic Perspectives, 12(2), 161-74.

Kuncoro, Mudrajad. 2001, Metóde Kuantitatif: Teori dan Aplikasi untuk Bisnis dan Ekonomi, Yogyakarta: AMP YKPN.

Kuncoro, Mudrajad.2002, Analisis Spasial dan Regional: Studi Aglomerasi dan Kluster Industri Indonesia, UPP AMP YKPN.

Kuncoro, Mudrajad. 2004. Otonomi.dan - Pembangunan Daerah: Reformasi, Perencanaan, Strategi, dan Peluang. Jakarta: Erlangga.

Malecki, E. J. 1991. Technology and Economic Development: the Dynamics of Local, Regional, and National Change. New York: John Wiley \& Sons, Inc.

Markusen, A. 1996. Sticky places in slippery space: A typology of industrial districts. Economic Geography, 72(3), 293 .

Maskell, P., Eskelinen, H., Hannibalsson, l., Malmberg, A., \& Vatne, W. 1997. Competitiveness, Localised Leaming and Regional Development. London and New York: Routledge.

McGee, T. G. 1991. The Emergence of Desakota Regions in Asia: Expanding a Hypothesis. In N. Ginsburg, B. Koppel, \& T. G. McGee (Eds.), The Extended Metropolis: Settlement
Transition in Asia . Honolulu: University of Hawaii Press.

Mody, Ashoka and Wang, Fang-Yi. 1997, Explaining Industrial Growth in Coastal China: Economic Reform . . : and What Else?, The World Bank Economic Review, 11(2): 293-325.

Montgomery, M. R. 1988, How Large is too Large? Implication of the City Size Literature for Population Policy and Research, Economic Development and Cultural Change, 36: 691-720.

Ottaviano, Gianmarco I.P. and Puga, Diego. 1988, Agglomeration in the Global Economy: A Survey of the 'New Economic Geography', The World New Economy, 21(6): 707-732.

Porter, M. E. 1998. Clusters and the New Economics of Competition. Harvard Business Review, November-December(6), 77-91.

Quigley, J. M. 1998. Urban Diversity and Economic Growth. Journal of Economic Perspectives, 12(2), 127-38.

Sveikauskas, L. 1975. The Productivity of Cities. Quarterly Journal of Economics, 89(3), 393-413.

UN. 1998. World Urbanization Prospects Thè 1996 Revision: Estimates and Projections of Urban and Rural Populations and of Urban Agglomerations. New York: Department of Economic and Social Affairs, Population Division, United Nations. 